\title{
Elanie Rodermond* and Frank Weerman \\ The families of Dutch terrorist suspects: Risk and protective factors among parents and siblings
}

https://doi.org/10.1515/mks-2021-0133

\begin{abstract}
Newsmedia have regularly reported about acts of terrorism that involved members of the same family, but also about instances where one sibling becomes a terrorist, whereas the other becomes a successful, law-abiding citizen. The question is, then, to what extent family circumstances and individual risk factors impact on pathways towards these shared or divergent outcomes. To date, studies on the family characteristics of terrorist suspects have been hampered by a lack of empirical data, small sample sizes and non-representative samples. Using register data on individuals suspected of a terrorist offense in the Netherlands and their family members, the present study examines the demographic and socio-economic characteristics of the families, as well as criminal, employment and education careers of individual family members (parents and brothers/sisters). We compare these characteristics with those of two control groups: suspects of non-terrorist offenses and a matched sample from the population. We also compared the terrorist suspects with matched siblings who were not suspected of a terrorist offence. We will end with a discussion of both risk and protective factors that are present within these families and that can put members of the same family on different pathways.
\end{abstract}

Keywords: terrorism suspects, family characteristics, siblings, risk factors, register data

\section{Introduction}

News media have regularly reported about acts of terrorism that involved members of the same family. For example, two brothers were identified amongst the perpetrators

*Corresponding author: Elanie Rodermond, Faculty of Law, Criminal Law and Criminology, VU University Amsterdam, De Boelelaan 1077, 1081 HV Amsterdam, The Netherlands, E-Mail: e.rodermond@vu.nl. Elanie is also affiliated to the Netherlands Institute for the Study of Crima and Law Enforcement, Amsterdam, the Netherlands.

Frank Weerman, Netherlands Institute for the Study of Crime and Law Enforcement, Amsterdam, the Netherlands. Frank Weerman is also affiliated to Erasmus School of Law, Criminology, Erasmus University Rotterdam. of the 2015 Brussels attacks, and two brothers were responsible for the Boston attack in 2013. More generally, involvement of brothers in acts of terrorism is not uncommon, and we have also seen co-involvement of sisters and sometimes even complete families (see for example Harris-Hogan, 2014). At the same time, there are some well-known examples of siblings taking completely different pathways towards either engagement in terrorism or leading a life as law-abiding citizen. More generally, the most common pattern among terrorist offenders seems to be that only one family member becomes suspected or convicted of a terrorist activity, while the others do not.

These observations raise the question whether there are specific family-level risk factors for terrorist engagement by one or more family-members. At the same time, they warrant attention for individual-level factors protecting persons from terrorist engagement, especially when one (or more) of their family-members is already engaged in terrorism. These questions fit well into a life-course criminological framework, which has a long tradition of focusing on individual as well as familial risk and protective factors for different types of offending (Farrington, 2003; Sampson \& Laub, 1997). Several studies have found evidence for a relation between the family-context and common forms of offending, shedding light at both risk and protective factors.

Taking this to the study of terrorism, recent years have seen an increase in the number of studies examining family-related risk factors for radicalization and terrorist engagement, as well as studies examining families of which multiple members have engaged in terrorism. These studies suggest that there are indeed direct and indirect influences of family-related factors on individual radicalization and terrorist engagement, just as has been found previously for regular offending. Examples of these factors are the presence of radicalized family-members (Asal \& Rethemeyer, 2008; Harris-Hogan, 2014; Lützinger, 2012; Post, Sprinzak \& Denny, 2003) and a family-situation characterized by a low-socioeconomic status and/or family instability (Sikkens, Sieckelinck, Van San, \& De Winter 2017; Simi, Sporer, \& Bubolz, 2016; Van Leyenhorst \& Andreas, 2017; Van San, 2015). While these studies and their findings are important, they are limited in scope and robustness. The majority of studies examining the family-- 
context of individuals who have engaged in terrorism has a qualitative or narrative methodology, and is based on small sample sizes, without a comparison group. As such, it is difficult to draw firm conclusions about the relative importance of risk and protective factors based on these studies. Also notably, it remains unclear which factors account for the divergent pathways described at the outset of this article. In other words, why do some individuals engage in terrorism, whereas their close relatives, in particular their siblings, do not?

The present study aims to narrow these gaps in our knowledge. Using data from a Dutch sample of 226 terrorist suspects, their (half)siblings and their (step)parents, we first compare the families of the terrorist suspects to two comparison groups: the families of regular suspects and the families of individuals from the general population. We study differences in family composition, family socioeconomic background and involvement in offending by family members. Next, we compare terrorist suspects with siblings (matched on age and gender as much as possible) who did not become a terrorist suspect.

\section{Previous research on family factors and terrorist offending}

Within the field of criminology, it is widely acknowledged that factors related to the family-context can influence individual pathways toward engagement in crime. For example, it has been found that certain structural family characteristics, such as divorced parents, large family size and low-socio-economic status increase the risk of offending and delinquency (Eichelsheim, 2019; Rekker, Pardini, Keijsers, Branje, Loeber, \& Meeus, 2015). Moreover, there is firm evidence for an association between criminal offending by parents or siblings and individual offending (Beijers, Bijleveld, Van de Weijer, \& Liefbroer, 2017, Buist, 2010; Huijsmans, Huijsmans, Eichelsheim, Weerman, Branje, \& Meeus, 2019; Thornberry, Feeman-Gallant, Lizotte, Krohn, \& Smith, 2003; Van de Rakt, Nieuwbeerta, \& Apel, 2009). Criminological studies also identified factors protecting individuals from delinquent behavior (see, for an overview, Lösel \& Farrington, 2012) at the family-level (e.g. a close relationship to at least one parent, medium family SES) as well as at the individual level (e.g. academic achievement, low impulsivity, nondeviant peers).

Compared to this body of research, much less is known about family factors related to terrorist offending (Harris-Hogan, 2014; Weggemans, Van der Zwan \& Liem, 2018). As mentioned, recent years have seen an increase in the amount of studies examining characteristics of families of which at least one members has radicalized or committed an act of terrorism. Some of these studies focused specifically on families with multiple radicalized individuals, trying to shed light on processes of intergenerational or intragenerational transmission of ideologies (Harris-Hogan, 2014). Other studies more generally examined characteristics of families that seem to increase the risk of radicalization of individuals by forming a "breeding ground' for radicalization (having a radicalized family member being just one of these factors) or contrastingly, serve as factors protecting individuals from radicalizing (Sikkens et al., 2017).

With regard to the first type of studies, a number of scholars found evidence for the intergenerational or intragenerational transmission of radical ideologies within families (Asal et al., 2008; Harris-Hogan, 2014; Post et al., 2003). Their studies showed that having close relatives who are involved with or supportive of terrorist organizations increase the likelihood of individuals engaging in terrorism. For example, Harris-Hogan (2014) showed that becoming part of a jihadist network is more likely when one or more family members are also involved. Moreover, Lützinger (2012) concluded that radicalized individuals who joined far-right extremist networks were often introduced to these networks by close relatives, most often siblings or cousins. Weggemans et al. (2018) conducted a qualitative study on the role of family members during the process of travelling to ISIS-controlled areas and returning back home. They interviewed several returned travelers, their family members, and professionals. Even though the travelers did not become involved in extremist networks themselves through their relatives, some of them did try to convince their siblings and sometimes even parents to travel to Syria (Weggemans et al., 2018).

With regard to the second type of studies, several studies show that radicalized individuals and terrorist offenders often come from families that are marked by a low socioeconomic status, financial problems and/or instable family situations (Sikkens et al., 2017; Simi et al., 2016; Van Leyenhorst \& Andreas, 2017; Van San, 2015; Versteegt, Ljujic, Bouk, Weerman, \& Van Maanen, 2018). Further, so-called Adverse Childhood Experiences (ACE's) within families have been found to increase the risk of engaging in violent extremism (Windisch, Simi, Blee, \& DeMichele, 2020). Windisch et al. (2020) found that among a group of former right-wing extremists they interviewed, two-thirds had experienced multiple (at least 4) ACE's, a higher percentage than amongst comparison groups of high-risk offenders and individuals from the general population. Van Leyenhorst and Andreas (2017) found that more than half of 
the suspects came from large families consisting of six or more siblings. Moreover, 9 suspects (out of a total of 26) grew up without the presence of a father.

Interestingly, recent studies have also reported characteristics at the family level that can decrease the chance to become involved in terrorist activities and can counteract existing risks (Lösel, King, Bender, \& Jugl, 2018; Lösel, Bender, Jugl, \& King, 2020; Wolfowicz, Litmanovitz, Weisburd, \& Hasisi, 2019) A systematic review of protective factors against radicalization (Lösel et al., 2018) reports that positive parenting strategies, non-violent 'significant others' and home ownership decrease the chance of radicalization. Moreover, parental involvement and interest in their children's lives were also found to be a factor that decreases the odds of radicalization. These family factors also protect against violent behaviour more generally (Lösel et al., 2018).

All in all, there is some evidence that family circumstances matter in the process of radicalization; on the one hand, specific circumstances, most notably having radicalized family members and growing up in problematic and poor socio-economic circumstances, can increase the risk of becoming involved in terrorist activities. On the other hand, positive family circumstances seem to protect from radicalization. Not much is known about the role of crime involvement of family members in general, and there is also no literature yet on the differences between terrorist and non-terrorist siblings from the same family. In this article, we investigate to what extent our results are in line with previous studies but also try to fill these gaps in the literature. We also extend previous research by comparing the families of terrorist suspects not only with families in general, but also with families of regular suspects. This will offer information about family factors that are related to offending in general and to terrorist offending more specifically.

\section{Method}

\subsection{Sample}

The present study is based on data on 226 individuals who have been suspected of 'crimes with terrorist intent' in the Netherlands ${ }^{1}$ since the introduction of the 'Law on terrorist crimes' in 2004 up until the end of our data-collection in

1 In order to be on the suspect list, there had to be 'serious indications' of a terrorist offense, leading to a transfer of the case to the public prosecutor.
April 2017, as well as their (step)parents and their (half) siblings. It builds on a previous examination of the backgrounds and criminal career of 279 terrorist suspects of the Netherlands. These individuals had been suspected of a variety of terrorist crimes, most often membership of a terrorist organisation, threatening to commit a terrorist crime or conspiracy to commit a terrorist crime (Rodermond \& Thijs, submitted). The ideological background of these crimes is unknown. However, the majority of suspects was registered between 2014 and April 2017. Given this, and given the relatively high number of foreign fighters that traveled (or attempted to travel) to Syria in that period, it is likely that a large part of the sample is accused of jihadi-inspired offenses.

A list with the personalia of the terrorist suspects was inserted into the secure environment of Statistics Netherlands (CBS) by the Dutch Public Prosecution Service. Within this secure environment, every inhabitant of the Netherlands has an encrypted number that allows for a connection between different datasets, without the risk of personal identification. Hence, once inserted in the CBS, the personalia of the terrorist suspects were replaced by this personal encrypted number. Through one of the datafiles on the Dutch population held by Statistics Netherlands, we could link the personal number of 226 terrorist suspects to the encrypted personal numbers of the suspects' (step)parents and all known children of their parents. This resulted in additional samples of 463 (step) parents and 792 (half)siblings. We further complemented this dataset with information on several life circumstances of the families such as household composition, as well as employment and education characteristics of the parents and the siblings (for more details, see svariables`).

Next, we created two control groups consisting of (1) regular suspects and (2) individuals from the general population. We used a case control matching procedure, resulting in control groups that matched the sample of terrorist suspects in terms of gender, age and migration background. To enlarge the control groups, we matched each terrorist suspects with five control group individuals. Hence, both control groups initially consisted of 1.130 individuals $(5 \times 226)$. After the formation of the control groups, we added the (step)parents and (half)siblings to these groups in the same way as we had done for the terrorist suspects. With regard to the general suspects, we could find one or both parents for 1.011 individuals, meaning that 119 individuals with no known information on their parents were left out of the analyses. With regard to the individuals from the general population, we could find one or more parents for 914 individuals, and the other 216 individuals were also left out of the analyses. After this 
procedure, we had 2.141 (step)parents and 3.596 (half)siblings for the general suspect control group, and 1.877 (step)parents and 3.020 (half)siblings for the general population control group.

Lastly, we created a small control group for the comparison between terrorist suspects and siblings who did not become a terrorist suspect themselves. We were able to match 159 terrorist suspects to 159 siblings that were comparable in terms of gender (137 brothers for 137 males and 22 sisters for 22 females) and age (siblings that differed not more than two years in age). The other terrorist suspects either did not have a sibling matching their own age and gender, or were a single child.

\subsection{Variables}

We used several datafiles extracted from the Social Statistics Database (SSB) from Statistics Netherlands (CBS) to gain information on employment, income and income support, education, previous accusations, periods in detention and household composition (i.e. married to or cohabiting with a partner, and/or living with children) in the period 2003 - 2016. We constructed dichotomous variables on a monthly level to examine the individuals' situation with regard to the different variables for each month in the studied period. For example, if the employment-dataset of the SSB indicated that an individual was employed from January 2008 until March 2008, and then again from June 2008 until September 2008, that individual would get a 1 for 'employedJanuary2008', 'employedFebruary2008', 'employedMarch2008', a 0 for 'employedApril2008', 'employedMay2008' and a 1 again for 'employedJune2008' and so on.

The variable employment recorded whether an individual was formally employed during a specific month. The variable qualified for job recorded whether an individual had the minimum level of education that is seen as required to enter the job market in the Netherlands (either higher levels of secondary education or the third grade of lower tertiary education). The variable registered income indicated whether an individual had a registered income (e.g. employment, social benefits). The variable mean registered income recorded the yearly income in Euro. The variable education recorded the highest level of education (lower, middle or higher, following the standard categorization of Statistics Netherlands). To measure whether an individual received a form of income support during a specific month, we constructed three variables, namely income support for unemployment, income support for disability and public assistance. To examine household com- position, we constructed 5 dummy variables, namely: living at the parental home, living alone, living with a partner (married and non-married) but without a child, living with a partner and children, and other ${ }^{2}$. Lastly, we constructed 7 variables about offending history: whether individuals had been accused of property offenses, public order offenses, violent offenses, traffic offenses, drugs offenses, weapon offenses and other offenses, and a variable to examine whether individuals had been in prison. For these criminal career variables, the SSB only holds information on a yearly level (whether an individual had been suspected of an offense or had been imprisoned somewhere during a specific year). As a result, these variables were recorded on a yearly level.

\subsection{Analyses}

In the present study, we followed different steps of mainly descriptive and comparative analyses, and conducted t-tests and chi-squares to determine statistical significance of the differences between groups ${ }^{3}$. First, we compared family composition and family demographic backgrounds of the terrorist suspects and the two control groups (criminal suspects and the general population). Next, we compared the parents/siblings of the terrorist suspects with those of the two control groups in terms of socioeconomic characteristics and criminal career. We compared (1) the families of the terrorist suspects with those of the regular suspects; (2) the families of the terrorist suspects with those of individuals from the general population; (3) the siblings of the terrorist suspects with the siblings of the regular suspects; (4) the siblings of the terrorist suspects with the siblings of the individuals from the general population. In the last step, we compared the terrorist suspects with their matched siblings in terms of socioeconomic characteristics and criminal career. During this last part of the analyses, we not only examined how the individuals fared throughout the complete studied period, but also focused on the situation one year prior to the terrorist accusation.

2 The >other « category consists of individuals living in an institutional household such as a caring facility, as well as individuals without a known household situation

3 We employ two-sided significance tests since we do not formulate hypotheses about the direction of our findings. Because of the exploratory character of our analyses we did not employ Bonferroni or other corrections for multiple testing. 
Table 1: Family composition and socioeconomic characteristics at the family-level

\begin{tabular}{|c|c|c|c|}
\hline & $\begin{array}{r}\text { Families terrorist } \\
\text { suspects (217) }\end{array}$ & $\begin{array}{l}\text { Families regular } \\
\text { suspects }(1.006)\end{array}$ & $\begin{array}{l}\text { Families general } \\
\text { population (912) }\end{array}$ \\
\hline \multicolumn{4}{|l|}{ Family composition } \\
\hline Mean number of siblings & 3,7 & 3,6 & $3,3^{*}$ \\
\hline Mean number full-siblings & 2,9 & 2,8 & 2,8 \\
\hline Mean number half-siblings & 0,4 & 0,3 & $0,2^{*}$ \\
\hline Number of families with half-siblings & $18,4 \%(40)$ & $15,9 \%(160)$ & $9,9 \%(91)^{\star \star}$ \\
\hline Number of families with step-mother & $15,7 \%(34)$ & $12,3 \%(124)$ & $8,8 \%(80)^{\star \star}$ \\
\hline Number of families with step-father & $5,1 \%(11)$ & $6 \%(60)$ & $2 \%(18)^{\star}$ \\
\hline \multicolumn{4}{|l|}{ Socioeconomic characteristics at family-level } \\
\hline Mean number of siblings with job qualification & 2 & 1,8 & 2 \\
\hline Mean number of siblings with lower education & 1,7 & 1,7 & $1,3^{\star \star}$ \\
\hline Mean number of siblings with middle education & 1,2 & 1,2 & 1,2 \\
\hline Mean number of siblings with higher education & 0,3 & $0,2^{\star}$ & 0,4 \\
\hline Mean family-income in Euro & 117.833 & 123.648 & $132.282^{\star *}$ \\
\hline
\end{tabular}

Note: $\sim p<.1^{*} p<.05^{* *} p<.01{ }^{* *} p<.001$, indicating significant differences between the families of terrorist suspects and the category where the symbol is placed

\section{Results}

\subsection{Family characteristics}

Table 1 compares the family composition and socioeconomic characteristics of the families of terrorist suspects, regular suspects and the general population. With regard to family composition, the table shows that the terrorist suspects come, on average, from larger families than individuals from the general population, with a mean number of 3,7 siblings (as compared to 3,3 siblings in the general population, a significant difference). No significant differences in size were found between families of terrorist suspects and that of regular suspects. Further, the findings point at a significantly higher proportion of broken families within the terrorist-suspect families as compared to the families from the general population; almost 20 percent of the families of terrorist suspects included half-siblings (as compared to 10 percent in the general population), in 15,7 percent a step-mother was present (vs. $8,8 \%$ ), and in 5,1 percent a stepfather (vs. $2 \%$ ).

Again, no significant differences were found between the terrorist-suspect families and the general-suspect families. With regard to socioeconomic characteristics at the family-level, the table shows that the families of terrorist suspects generally have a lower socioeconomic position than the families of the general population, with a higher mean number of siblings with lower education and a sig- nificantly lower mean family-income. No significant differences were found for the mean number of siblings with a job qualification (a mean around 2 in all groups of families) and for the mean number of siblings with middle education (1,2 in all groups).

\subsection{Socioeconomic characteristics of family members}

Next, Table 2 provides a more detailed picture of the individual socioeconomic characteristics ${ }^{4}$ of the parents and siblings from the three groups. Looking at the highest level of education of the siblings, we found more similarities than differences between the groups. In all three groups, lower education as the highest level of education is dominant, followed by middle education. Interestingly, the siblings of the terrorist suspects are slightly more often higher educated than the siblings of the general suspects $(9,8$ vs. $7,2 \%, p<0,05)$. There were no significant differences be-

4 As mentioned before, data on education was missing for the majority of parents. Therefore, we are only able to present this information for the siblings. More generally, there were a lot of missings in the data on education, as can be seen in Table 2 . This should be kept in mind when looking at the number of individuals with lower, middle and higher education. 
Table 2: Socioeconomic characteristics of the parents and siblings of terrorist suspects and the control groups

\begin{tabular}{|c|c|c|c|c|c|c|}
\hline & $\begin{array}{l}\text { Parents } \\
\text { terrorist } \\
\text { suspects } \\
(463)\end{array}$ & $\begin{array}{l}\text { Parents } \\
\text { regular } \\
\text { suspects } \\
(2.141)\end{array}$ & $\begin{array}{l}\text { Parents } \\
\text { general popu- } \\
\text { lation } \\
(1.877)\end{array}$ & $\begin{array}{l}\text { Siblings } \\
\text { terrorist } \\
\text { suspects } \\
(792)\end{array}$ & $\begin{array}{l}\text { Siblings } \\
\text { regular } \\
\text { suspects } \\
(3.596)\end{array}$ & $\begin{array}{l}\text { Siblings } \\
\text { general } \\
\text { population } \\
(\mathbf{3 . 0 2 0 )}\end{array}$ \\
\hline \multicolumn{7}{|c|}{ Highest level of education } \\
\hline Lower & & & & $39,0 \%(309)$ & $41,4 \%(1.490)$ & $35,9 \%(1.083)$ \\
\hline Middle & & & & $28,2 \%(223)$ & $29,4 \%(1.056)$ & $30,0 \%(905)$ \\
\hline Higher & & & & $9,8 \%(78)$ & $7,2 \%(258)$ & $10,8 \%(325)$ \\
\hline Missing & & & & $23,0 \%(182)$ & $22,0 \%(792)^{\star}$ & $23,4 \%(707)$ \\
\hline \multicolumn{7}{|l|}{ Qualified for job } \\
\hline Yes & & & & $38,0 \%(301)$ & $36,5 \%(1.314)$ & $40,7 \%(1.230)$ \\
\hline No & & & & $39,0 \%(309)$ & $41,3 \%(1.490)$ & $35,9 \%(1.083)$ \\
\hline Missing & & & & $23,0 \%(182)$ & $22,0 \%(792)$ & $23,4 \%(707)$ \\
\hline \multicolumn{7}{|l|}{ Employed in 2016} \\
\hline Yes & $22,0 \%(102)$ & $21,5 \%(461)$ & $25,3 \%(475)$ & $44,1 \%(349)$ & $47,5 \%(1.709)^{\star}$ & $50,4 \%(1.521)^{\star \star}$ \\
\hline No & $78,0 \%(361)$ & $78,5 \%(1.680)$ & $74,7 \%(1.402)$ & $55,9 \%(443)$ & $52,5 \%(1.887)$ & $49,6 \%(1.499)$ \\
\hline \multicolumn{7}{|c|}{ Mean number of months employed in } \\
\hline \multicolumn{7}{|l|}{ Income support in 2016} \\
\hline Disability & $9,5 \%(44)$ & $11,1 \%(237)$ & $8,9 \%(167)$ & $9,3 \%(74)$ & $8,2 \%(294)$ & $8,0 \%(243)$ \\
\hline Public assistance & $27,2 \%(126)$ & $23,1 \%(495) \sim$ & $16,4 \%(308)^{\star \star \star}$ & $16,7 \%(132)$ & $14,5 \%(520)$ & $10,8 \%(325)^{\star \star}$ \\
\hline Unemployment & $4,1 \%(19)$ & $3,4 \%(73)$ & $3,5 \%(66)$ & $4,5 \%(36)$ & $5,9 \%(213)$ & $5,8 \%(174)$ \\
\hline \multicolumn{7}{|c|}{ Registered income in 2016} \\
\hline Yes & $72,6 \%(336)$ & $73,3 \%(1.569)$ & $71,8(1.348)$ & $71,7 \%(568)$ & $74,0 \%(2.662)$ & $72,3 \%(2.183)$ \\
\hline No & $27,4 \%(127)$ & $26,7 \%(572)$ & $28,2 \%(529)$ & $28,3 \%(224)$ & $26,0 \%(934)$ & $27,7 \%(837)$ \\
\hline \multicolumn{7}{|c|}{ Mean (registered) income in 2016 in } \\
\hline Euro & 25.949 & 24.960 & 27.817 & 23.157 & $25.382^{\star}$ & $27.827^{\star \star \star}$ \\
\hline
\end{tabular}

Note: $\sim p<.1^{*} p<.05^{* *} p<.01^{* * *} p<.001$ indicating significant differences between the parents/siblings of the terrorist suspects and the parents/siblings of the category where the symbol is placed

tween the three groups in the proportion of siblings that had a high enough education to be qualified for a job.

The siblings of the regular suspects, as well as the siblings of the general population, were significantly more often employed in 2016 than the siblings of the terrorist suspects. Looking at the complete period under study (from 2005-2016), the siblings of the general population were employed for more months on average than the siblings of the terrorist suspects (58,9 vs. 52,5 months, $p<$ $.05)$. For the parents, no differences for employment were found between the three groups, with the majority of parents being unemployed in 2016. This is likely the result of their mean age, as a lot of the parents had probably retired already.A higher percentage of siblings of terrorist suspects as compared to the siblings of general suspects received public assistance in $2016(16,7 \%$ vs. 10,8\%, $\mathrm{p}<$.01). Likewise, the percentage of parents of terrorist suspects receiving public assistance $(27,2 \%)$ is (marginally) significantly higher than that of parents of general suspects $(23,1 \%, p<.1))$ and parents of the general population
$(16,4 \%, p<.001))$. Finally, no differences were found for the number of siblings and parents who had a registered income in 2016 (around three quarters in all groups). However, the siblings of the regular suspects and the general populations had, on average, a higher mean registered income (taking into account only those siblings with a registered income).

\subsection{Criminal history of family members}

Next, we examined previous accusations against the parents and siblings of all groups. As can be seen in Table 3, $34,0 \%$ of the siblings of terrorist suspects was accused of an offense in the period 2005-2016, a higher percentage than in the sibling-group of the general population $(28,2 \%, p<.01)$, but a lower percentage than in the sibling-group of the regular suspects $(38,8 \%, p<.05)$. Of those siblings who were accused of offenses, the largest percentage (in all three groups) was accused of 2 to 5 of- 
Table 3: Criminal history of the parents and siblings of the terrorist suspects and the control groups

\begin{tabular}{|c|c|c|c|c|c|c|}
\hline & $\begin{array}{l}\text { Parents terrorist } \\
\text { suspects } \\
\text { (463) }\end{array}$ & $\begin{array}{l}\text { Parents general } \\
\text { suspects } \\
(2141)\end{array}$ & $\begin{array}{l}\text { Parents general } \\
\text { population } \\
(1877)\end{array}$ & $\begin{array}{l}\text { Siblings terrorist } \\
\text { suspects } \\
(792)\end{array}$ & $\begin{array}{l}\text { Siblings general } \\
\text { suspects } \\
(3.596)\end{array}$ & $\begin{array}{l}\text { Siblings general } \\
\text { population } \\
(3.020)\end{array}$ \\
\hline Ever accused & $16,0 \%(74)$ & $20,6 \%(366)$ & $9,1 \%(171)^{\star \star \star}$ & $34,0 \%(269)$ & $38,8 \%(1.395)^{\star}$ & $28,2 \%(851)^{\star \star}$ \\
\hline \multicolumn{7}{|c|}{ Number of accusations: } \\
\hline None & $84,0 \%(389)$ & $83,0 \%(1.775)$ & $90,9 \%(1.706)$ & $66,0 \%(523)$ & $61,2 \%(2.210)$ & $71,8 \%(2.170)$ \\
\hline 1 & $11,2 \%(52)$ & $9,2 \%(198)$ & $5,5 \%(103)$ & $11,5 \%(91)$ & $11,3 \%(409)$ & $10,3 \%(310)$ \\
\hline $2-5$ & $4,8 \%(22)^{5}$ & $7,8 \%(168)$ & $3,6 \%(68)$ & $13,0 \%(103)$ & $15,0 \%(543)$ & $11,0 \%(331)$ \\
\hline $6-9$ & - & - & - & $3,9 \%(31)$ & $4,5 \%(162)$ & $3,0 \%(91)$ \\
\hline $10-19$ & - & - & - & $3,3 \%(26)$ & $5,2 \%(189)$ & $2,5 \%(76)$ \\
\hline$>-20$ & - & - & - & $2,3 \%(18)$ & $2,7 \%(98)$ & $1,5 \%(44)$ \\
\hline Mean & 0,3 & $0,5^{\star}$ & $0,2^{\star}$ & 1,9 & $2,5^{\star}$ & $1,4^{*}$ \\
\hline \multicolumn{7}{|c|}{ Accused of the following crimes: } \\
\hline Property & $4,3 \%(20)$ & $6,4 \%(136)$ & $2,9 \%(54)$ & $20,5 \%(162)$ & $24,2 \%(872)^{\star}$ & $15,6 \%(470)^{\star \star}$ \\
\hline Public order & $1,5 \%(7)$ & $2,7 \%(58)$ & $1,0 \%(19)$ & $10,7 \%(85)$ & $14,5 \%(522)^{\star \star}$ & $9,2 \%(278)$ \\
\hline Violence & $7,8 \%(36)$ & $7,5 \%(161)$ & $3,4 \%(64)^{\star \star}$ & $15,7 \%(124)$ & $20,0 \%(719)^{\star \star}$ & $13,1 \%(396)^{\star}$ \\
\hline Traffic & $2,4 \%(11)$ & $3,9 \%(83)$ & $2,5 \%(46)$ & $6,3 \%(50)$ & $10,2 \%(367)^{\star \star}$ & $6,9 \%(208)$ \\
\hline Drugs & $1,9 \%(9)$ & $2,1 \%(44)$ & $1,2 \%(23)$ & $6,4 \%(51)$ & $8,3 \%(300)$ & $6,7 \%(201)$ \\
\hline Weapons & - & - & - & $2,7 \%(21)$ & $3,4 \%(123)^{\star \star}$ & $1,8 \%(55)$ \\
\hline Other & $1,5 \%(7)$ & $1,6 \%(35)$ & $0,9 \%(17)$ & $3,5 \%(28)$ & $5,6 \%(203)^{\star \star}$ & $3,5 \%(105)$ \\
\hline Ever imprisoned & $1,7 \%(8)$ & $2,7 \%(57)$ & $1,5 \%(28)$ & $10,7 \%(85)$ & $12,4 \%(446)$ & $7.3 \%(222)^{\star \star}$ \\
\hline
\end{tabular}

Note: $\sim p<.1^{*} p<.05^{* *} p<.01^{* *} p<.001$ indicating significant differences between the parents/siblings of the terrorist suspects and the parents/siblings of the category where the symbol is placed

fenses. Around 10 percent of siblings with a previous accusation was accused only once. For each sibling-group there is a small sub-group with 20 or more accusations.

Interestingly, the siblings of the regular suspects appear to be most criminally active, with a significantly higher mean number of previous accusations, as well as a larger proportion of siblings who were accused 6 times or more. Zooming in on the parents, it is found that $16 \%$ of the parents of terrorist suspects was ever accused of an offense, a percentage almost twice as high as that of the general population parents $(9,1 \%, \mathrm{p}<.001)$. However, an even higher percentage of the parents of regular suspects was ever accused of an offense (20,6\%), and these parents also showed the highest mean number of offenses $(0,5$, as compared to 0,3 amongst the parents of terrorist suspects).

An examination of the type of offenses indicates that, for all groups, the largest proportion of the accused sib-

5 Due to the low number of parents who fell in the different categories (i.e. 2-5, 6-9, 10-19, >-20) we needed to combine these into one category ' 2 or more'. For the sake of readability, we did not add another category just for the parents. As such, for the parents, the category 2-5 actually means 2 or more. lings was accused of property crimes, followed by violent offenses and public order offenses. Again, the siblings of the regular suspects show the highest percentage in each category, followed by the siblings of the terrorist suspects. Interestingly, the parents in all groups were more often accused of violent offenses than property offenses. Here, the parents of terrorist suspects and regular suspects are showing similar percentages; $7,8 \%$ of the parents of terrorist suspects was suspected of a violent offense, and $7,5 \%$ of parents or regular suspects, whereas only $3,4 \%$ of parents of the general population was suspected of a violent offense. A smaller percentage of all parent-groups has been accused of property crimes, followed by traffic offenses and public order and drug offenses. Finally, a significantly higher percentage of siblings of terrorist suspects has ever been imprisoned as compared to the siblings of the general population, namely $10,7 \%$ (vs. 7,3\% of the general population siblings). No differences in the occurrence of imprisonment were found between the siblings of the terrorist suspects and those of the general suspects, and the same holds true for all groups of parents.

All in all, it can be concluded that the criminal history of the family-members of terrorist suspects resembles that 
Table 4: Comparing socio-economic characteristics of the terrorist suspects and their matched siblings (one year prior to the terrorist suspicion)

\begin{tabular}{|c|c|c|}
\hline & Terrorist suspects (159) & Matched siblings (159) \\
\hline \multicolumn{3}{|l|}{ Seks } \\
\hline Male & $86,2 \%(137)$ & $86,2 \%(137)$ \\
\hline Female & $13,8 \%(22)$ & $13,8 \%(22)$ \\
\hline \multicolumn{3}{|l|}{ Highest educational level } \\
\hline Lower & $45,9 \%(73)$ & $40,3 \%(64)$ \\
\hline Middle & $27,7 \%(44)$ & $28,3 \%(45)$ \\
\hline Higher & $4,4 \%(7)$ & $8,2 \%(13)$ \\
\hline Employed for at least one month* & $40,9 \%(65)$ & $54,7 \%(87)$ \\
\hline Employed the entire year* & $16,4 \%(26)$ & $30,8 \%(49)$ \\
\hline \multicolumn{3}{|l|}{ Income support } \\
\hline Disability & $5,7 \%(9)$ & $3,8 \%(6)$ \\
\hline Public assistance & $13,8 \%(22)$ & $10,7 \%(170)$ \\
\hline Registered income & $74,8 \%(119)$ & $80,5 \%(128)$ \\
\hline Mean income in Euro (in case of a registered income)* & 16.210 & 24.009 \\
\hline \multicolumn{3}{|l|}{ Place in household } \\
\hline Living at the parental home & $37,1 \%(59)$ & $29,6 \%(47)$ \\
\hline Single & $15,7 \%(28)$ & $18,9 \%(30)$ \\
\hline Partner (married and unmarried)* & $7,5 \%(12)$ & $13,8 \%(22)$ \\
\hline Partner (married and unmarried) and (a) child(ren)* & $11,9 \%(19)$ & $19,5 \%(31)$ \\
\hline Another household & $22,0 \%(22)$ & $11,3 \%(18)$ \\
\hline
\end{tabular}

Note: ${ }^{*} p<.05^{* *} p<.01$

of the family-members of the regular suspects, although the total number of accusations and imprisonment rates are slightly lower amongst the siblings and parents of terrorist suspects. The family-members of the individuals from the general population are less often involved in crime, and when they are, they are suspected of less offenses than the other groups of siblings and parents.

\subsection{Matched comparison between terrorist suspects and their siblings}

Lastly, we compared the terrorist suspects themselves with a comparable sibling (matched on gender and age). As mentioned before, we were able to match 137 male and 22 female suspects, leading to a total sample for this analysis of 318 individuals (159 terrorist suspects and 159 siblings). Importantly, we focused now on the year prior to the terrorist suspicion (as opposed to the previous analyses, which were focused on either the full studied period, or the year 2016). By examining the year prior to the terrorist suspicion, we tried to avoid confusion between cause and effect. The results of the analyses are presented in Table 4.

First, Table 4 shows that there are no significant differences between terrorist suspects and their matched siblings with regard to the educational level. Lower education is most common in both groups, followed by middle education. A small percentage of both groups is higher educated, although the percentage is slightly (but not significantly) higher in the group of siblings. Looking at employment, some differences emerge. A significantly larger proportion of siblings was employed for at least one month in the year prior to the terrorist suspicion, as compared to the terrorist suspects $(54,7 \%$ of the siblings, as compared to $40,9 \%$ of the terrorist suspects, $\mathrm{p}<.05$ ). Moreover, a larger proportion of siblings compared to the terrorist suspects was employed the entire year (30,8\% vs. $16,4 \%, p<.05)$. As for income support, no significant differences are found. However, the mean income of siblings is significantly higher than that of the terrorist suspects $(\mathrm{p}<.05)$.

Lastly, looking at the individuals' household situation, Table 4 shows that siblings of the terrorist suspects 
Table 5: Comparing criminal history of the terrorist suspects and their matched siblings

\begin{tabular}{|c|c|c|}
\hline & Terrorist suspects (159) & Matched siblings (159) \\
\hline \multicolumn{3}{|c|}{ One year prior to terrorist accusation } \\
\hline Accused of an offence $e^{\star \star}$ & $27,7 \%(44)$ & $10,7 \%(17)$ \\
\hline Accused of $a$ : & $4,4 \%(7)$ & $2,5 \%(4)$ \\
\hline Property offense & $6,9 \%(11)$ & $1,3 \%(2)$ \\
\hline Public order offense* & $10,1 \%(16)$ & $1,9 \%(3)$ \\
\hline Violent offense ${ }^{\star}$ & $1,9 \%(3)$ & $1,9 \%(3)$ \\
\hline Traffic offense & $1,3 \%(2)$ & $1,9 \%(3)$ \\
\hline Drugs offense & - & $1,9 \%(3)$ \\
\hline Weapon offense & $2,5 \%(4)$ & . \\
\hline \multicolumn{3}{|l|}{ Other offense $e^{\star \star}$} \\
\hline Imprisoned at least one day** & $12,6 \%(20)$ & $0,6 \%(1)$ \\
\hline \multicolumn{3}{|l|}{ In the period $2005-2017$} \\
\hline Mean number of accusations ${ }^{\star \star \star}$ & 7,4 & 2,8 \\
\hline Accused of $a$ : & $42,8 \%(68)$ & $28,9 \%(46)$ \\
\hline Property offense* & $40,9 \%(65)$ & $21,4 \%(34)$ \\
\hline Public order offense ${ }^{\star \star}$ & $57,2 \%(91)$ & $24,5 \%(39)$ \\
\hline Violent offense ${ }^{\star \star}$ & $16,4 \%(26)$ & $10,1 \%(16)$ \\
\hline Traffic offense & $13,8 \%(22)$ & $11,3 \%(18)$ \\
\hline Drugs offense & $10,0 \%(16)$ & $6,3 \%(10)$ \\
\hline Weapon offense & $18,9 \%(30)$ & $4,4 \%(7)$ \\
\hline \multicolumn{3}{|l|}{ Other offense* } \\
\hline Ever imprisoned ${ }^{\star \star}$ & $64,8 \%$ (103) & $17,6 \%(28)$ \\
\hline
\end{tabular}

Note: ${ }^{\star} \mathrm{p}<.05{ }^{\star \star} \mathrm{p}<.01{ }^{\star \star \star} \mathrm{p}<.001$

are significantly more often living with a partner than the terrorist suspects themselves, as well as with a partner and children. Terrorist suspects, on the other hand, are more often than their siblings living at home with their parents, although this difference is not significant. They are also more often in 'another household', which can be in prison or residential care. However again, this difference was not significant. Finally, we compared the criminal history of the terrorist suspects with that of their siblings in terms of the number of accusations in the year prior to the terrorist suspicion, the overall number of previous accusations, the types of crimes, and periods of imprisonment. As can be seen in Table 5, a significantly higher number of terrorist suspects was accused of an offense one year prior to the terrorist accusation, as compared to their siblings (27,7\% vs. $10,7 \%, \mathrm{p}<.01)$. Moreover, they were much more likely to have been in prison for at least one day $(12.6 \%$ vs. $0,6 \%, p<.01$ ). Looking at the types of crimes, over 10 percent of the terrorist suspects was accused of a violent crime, followed by public order offenses $(6,9 \%)$ and property offenses $(4,4 \%)$. Only a small number of siblings was accused of each type of offense (ranging from 2,5\% accused of property offenses to 1,3\% accused of public order offenses). As for the overall study period, the terrorist sus- pects were accused of an offense almost three times as often as their siblings (7,4 times as compared to 2,8 times, $\mathrm{p}<$ .001). Moreover, two-thirds of the terrorist suspects had been imprisoned at least one day (as opposed to $17,6 \%$ of the siblings).

Zooming in on the types of crimes, almost 60 percent of the terrorist suspects had been suspected of a violent offense, over 40 percent had been suspected of a property offense, and also 40 percent had been suspected of a public order offense. As can be expected on the basis of the overall number of accusations, the siblings show significantly lower numbers in each offense category: $24,5 \% \mathrm{had}$ been accused of a violent offense, $28,9 \%$ of a property offense, and $21,4 \%$ of a public order offense. No significant differences were found in the relatively small numbers of individuals who had been accused of traffic, drugs and weapon offenses. All in all, it can be concluded that the terrorist suspects have a more extensive criminal history, in terms of accusations as well as incarceration history. 


\section{Discussion}

There is an abundance of empirical research exploring the association between factors related to the family-context and regular offending, shedding light on both risk and protective factors for criminal involvement. However, when it comes to terrorist offending, much less is known about the role of family factors. Employing data on individuals who have been suspected of 'crimes with terrorist intent' in the Netherlands, linked to data on their (step) parents and their (half)siblings, the present study addressed this gap in knowledge by comparing the families of terrorist suspects with those of regular suspects and families from the general population in terms of family composition, socio-economic circumstances and criminal history. Moreover, we compared the terrorist suspects with their siblings (matched on gender and age) to find risk and protective factors connected to within-family differences in the year prior to the terrorist accusation.

The results of the study show that terrorist suspects come, on average, from larger families than individuals from the general population and more often from broken families. No differences in family composition were found between the terrorist suspects and the regular suspects. Further, families of terrorist suspects generally have a lower socioeconomic position than the families of the general population, and a more extensive criminal history (this holds for the siblings as well as the parents of the terrorist suspects). Again, no substantive differences were found between the families of the terrorist suspects and those of the regular suspects, even though the latter families showed, on average, slightly higher offending rates. Together, these findings show that the families of terrorist suspects resemble those of regular suspects in many respects, whereas they differ from the general population families.

Findings from the comparison between terrorist suspects and their siblings one year prior to the terrorist suspicion provide additional insights about the familiy context of terrorist offending by pointing at differences within families. Although we did not find differences with regard to the educational level (with lower education being most common in both groups), a larger proportion of matched siblings was employed in the year prior to the terrorist accusation, and they had a higher mean income. Looking at the household situation, siblings of terrorist suspects were more often in a cohabiting relationship (either with or without children), whereas the terrorist suspects themselves more often lived with their parents, or where part of 'another household', for example prison or residential care. Lastly, the terrorist suspects had more extensive criminal histories than their siblings (in terms of accusa- tions as well as incarceration history), both in the year prior to the terrorist accusation and in the overall studied period. Overall, the siblings appeared to fare better than the terrorist suspects.

The quantitative and exploratory nature of the present study does not allow for firm conclusions about the mechanisms underlying our findings. Nevertheless, we can provide some tentative thoughts about the interpretation of the results. First of all, it is unlikely that the less beneficial family characteristics of terrorist suspects (lower socio-economic status, different family composition and more crime involvement than the families of the general population) had a direct effect on becoming a terrorist suspect. Rather, these family characteristics can be considered as what has been referred to as "conditioning experiences that incrementally increase a person's susceptibility to negative outcomes (Simi et al., p. 553). As such, results seem to support the 'breeding ground hypothesis' described earlier in this article. Specific family circumstances might increase the risk of becoming a terrorist suspect, just as these circumstances have been found to increase the risk of other forms of offending previously (see for example Rekker et al., 2015).

Secondly, the comparison between terrorist suspects and siblings resulted in a number of factors, most notably relating to informal social control and economic factors, that can be considered protective. Even though we are unable to test it directly, it could be that the higher levels of terrorist siblings' cohabiting relationships and employment both served as 'a stake in conformity' (Sampson \& Laub, 1997). According to Lösel et al. (2018), studies have consistently found attachment to society to be a protective factor against radicalization, and our findings seem to support this notion. At the same time, being employed and, relatedly, having an income, might have prevent feelings of strain, which have been linked to forms of offending as well as radicalization in previous studies (Agnew, 2010). Future research is needed to further investigate the mechanisms underlying the relationships between terrorist offending and family factors and within-family differences.

\section{Limitations}

The present study has several limitations. First of all, we had to rely on accusations rather than on convictions: our extended dataset was based on a list of individuals suspected of a crime with terrorist intent. Even though there had to be 'serious indications' of such a crime, leading the police to transfer the case to the public prosecutor, we cannot rule out the possibility that a few false positives 
remained in the original dataset. We also had no detailed information about the content of the accusations. This means that our sample of terrorist suspects is very heterogeneous, consisting of suspects of planning attacks, foreign fighting and supporting terrorist actions or travelling to Syria or Iraq. As mentioned previously, we do not have any information on the ideological background of the accusation. Even though we assume that the majority of individuals in our dataset is accused of a jihadi-inspired offense, it is likely that at least part of the suspects have a right-wing extremist background. However, as these backgrounds are not listed, we are unable to compare individuals based on their ideological background.

We also cannot be sure about the causal ordering of our variables. For example, it is possible that terrorist accusations may place family members under a magnifying glass, which leads to an enhanced chance of suspicions against parents and siblings. Related to this, it is even possible that part of the less beneficial circumstances of the families of terrorist suspects were not preceding but rather resulting from having a family member who is accused of a terrorist crime because such an accusation might have caused a backlash to the complete family. In the comparison between terrorist offenders and their siblings, we tried to avoid such confusion by examining the year prior to the terrorist accusation. With regard to our matching procedure one has to keep in mind that terrorist suspects without siblings or comparable siblings were left out of the final analyses. It could be that these terrorist suspects differ from the ones we were able to include, for example in terms of socio-economic status.

Finally, a major limitation is that we only investigated descriptive and quantitative characteristics of families and family members. The nature of the present study, based on official registrations and links to a statistics database, made it impossible to examine more in-depth family-related characteristics and circumstances that might increase or reduce the risk of radicalization and terrorist engagement. Examples of these are discrimination and perceived threats, adverse childhood circumstances, parenting styles and the broader social network of the families and family members. Future studies might explore these variables more broadly and in more detail.

Acknowledging these limitations, the present study should be considered an exploratory first step towards furthering our understanding of the family context of terrorism. It indicates that indeed specific family circumstances might increase the risk of engaging in terrorism, and that protective factors amongst family members might counteract these circumstances.

\section{References}

Agnew, R. (2010). A general strain theory of terrorism. Theoretical Criminology 14(2):131-153.

Asal, V., \& Rethemeyer, R.K. (2008). Dilettantes, ideologues, and the weak. Conflict Management and Peace Science, 25(3), 244-263.

Beijers, J.E.H., Bijleveld, C.C.J.H., Van de Weijer, S.G.A., \& Liefbroer, A. (2017). 'All in the family?' The relationship between sibling offending and offending risk. Journal of Developmental and Life-Course Criminology, 3(1), 1-14.

Buist, K.L. (2010). Sibling relationship quality and adolescent delinquency: A latent growth curve approach. Journal of Family Psychology, 24(4), 400-410.

Eichelsheim, V. (2019). Crimineel gedrag over de levensloop én over generaties: De rol van het gezin. Tijdschrift voor Criminologie, 61 (2), 132-147.

Farrington, D.P. (2003). Developmental and life-course criminology: key theoretical and empirical issues-the 2002 Sutherland award address. Criminology, 41(2), 221-255

Harris-Hogan, S. (2014). The importance of family: The key to understanding the evolution of Jihadism in Australia. Security Challenges, 10(1), 31-49.

Huijsmans, T., Eichelsheim, V.I., Weerman, F.M., Branje, S.J.T., \& Meeus, W. (2019). The role of siblings in adolescent delinquency next to parents, school, and peers: Do gender and age matter? Journal of Developmental and Life-Course Criminology, 5(2), 220-242.

Lösel F., Bender D., Jugl I., King S. (2020) Resilience against Political and Religious Extremism, Radicalization, and Related Violence: A Systematic Review of Studies on Protective Factors. In: Weisburd D., Savona E., Hasisi B., Calderoni F. (eds) Understanding Recruitment to Organized Crime and Terrorism. Cham: Springer.

Lösel, F., \& Farrington, D.P. (2012). Direct protective and buffering protective factors in the development of youth violence. American Journal of Preventive Medicine, 43(2), S8-S23.

Lösel, F., King, S., Bender, D., \& Jugl, I. (2018). Protective factors against extremism and violent radicalization: A systematic review of research. International Journal of Developmental Science, 12(1-2), 89-102.

Lützinger, S. (2012). The other side of the story: A qualitative study of the biographies of extremists and terrorists. Wiesbaden: Bundeskriminalamt.

Post, J.M., Sprinzak, E., \& Denny, L.M. (2003). The terrorists in their own words: Interviews with 35 incarcerated Middle-East terrorists. Terrorism and Political Violence, 15(1), 171-184.

Rekker, R., Pardini, D., Keijsers, L., Branje, S., Loeber, R., \& Meeus, W. (2015). Moving in and out of poverty: The within-individual association between socioeconomic status and juvenile delinquency. PLoS One, 10(11).

Rodermond, E., \& Thijs, F. (2021). From crime to terrorism: Life-circumstances and criminal careers of terrorist suspects. Manuscript submitted for publication.

Sampson \& Laub (1997) A Life-course theory of cumulative disadvantage and the stability of delinquency. In Thornberry (ed.). Developmental theories of crime and delinquency: Advances in criminological theory, pp. 133-161. New Jersey: Transaction Publishers.

Sikkens, E., Sieckelinck, S., Van San, M., \& de Winter, M. (2017). Parental reaction towards radicalization in young people. Child \& Family Social Work, 22(2), 1044-1053. 
Simi, P., Sporer, K., \& Bubolz, B.F. (2016). Narratives of childhood adversity and adolescent misconduct as precursors to violent extremism. Journal of Research in Crime and Delinquency, 53(4), 536-563.

Thornberry, T., Feeman-Gallant, A., Lizotte, A., Krohn, M., \& Smith, C. (2003). Linked lives: The intergenerational transmission of antisocial behaviour. Journal of Abnormal Child Psychology, 31(2), 171-184

Van Leyenhorst, M., \& Andreas, A. (2017). Dutch suspects of terrorist activity: a study of their biographical backgrounds based on primary sources. Journal for Deradicalization (3)12, 309-344.

Van San, M. (2015). Onze kinderen zijn geen terroristen: Families van Belgische en Nederlandse Syriëgangers over het vertrek van hun geliefden. Tijdschrift voor Criminologie, 57(3), 300-314.

Van de Rakt, M., Nieuwbeerta, P., \& Apel, R. (2009). Association of criminal convictions between family members: Effects of siblings, fathers and mothers. Criminal Behaviour and Mental Health, 19(2), 94-108.
Versteegt, I., Ljujic, V., El Bouk, F., Weerman, F., \& Van Maanen, F. (2018). Terrorism, Adversity and Identity: A Qualitative Study of Detained Terrorism Suspects in Comparison to Other Detainees. Amsterdam, NSCR.

Weggemans, D., Van der Zwan, M., \& Liem, M. (2018). Familie van Uitreizigers. Een Onderzoek naar De Rol van Familieleden bij Processen van Uitreizen naar en Terugkeren uit Buitenlandse Jihadistische Strijdgroepen. Den Haag: WODC.

Windisch, S., Simi, P., Blee, K.M., \& DeMichele, M. (2020). On the permissibility of homicidal violence: Perspectives from former U.S. white supremacists. Perspectives on Terrorism, 14(6), 65-76.

Wolfowicz, M., Litmanovitz, Y., Weisburd, D., \& Hasisi, B. (2019). A field-wide systematic review and meta-analysis of putative risk and protective factors for radicalization outcomes. Journal of Quantitative Criminology, 36, 407-447. 